\title{
Alexandru Philippide, Originea românilor, vol. I și II, ediția a II-a, ediție de Roxana Vieru, prefată de Carmen-Gabriela Pamfil, postfată de Alexandru Gafton, Editura Universității „Alexandru Ioan Cuza”, Iași, 2014/2015, 802/763 p.
}

\author{
Enikő Pál* \\ Faculty of Economics, Socio-Human Sciences and Engineering, Sapientia University, Piața Libertății 1, 530104 Miercurea Ciuc, Romania
}

Language sciences are one of those research fields which ensure their perpetuation by the very subject matter thereof. In contrast, the scientific endeavours which aim at its study must stand the test of time, or, more precisely, that of progress. In our opinion, besides proving the validity and accuracy of the scientific content gathered within such an endeavour, another prerequisite for achievement, not insignificant at all, resides in the express or implied stakes of the approach to the issue dealt with. Thus, in the majority of cases, the fundamental works which managed to persist offer a glimpse of the general matter beyond the particular and individual facts represented by the different historical languages taken separately, offering some insight into the whole configuration beyond the component elements thereof represented by the different domains of the languages in question; in short, they show the generic manoeuvring mechanisms of the common activity and product known as "language". In this respect, only a few Romanian linguists have succeeded in turning the study of Romanian language into a universal subject matter of knowledge, attempting at the same time to place Romanian linguistics within the realm of general linguistics. Among them there is Alexandru Philippide, "the greatest Romanian linguist of all times, perhaps the only one who stands effortlessly alongside the great linguists of the world" (Gafton, Postface to vol. II, 2015).
Performing his activity in a period of great turmoil and contradictions, Alexandru Philippide is remarkable first and foremost for the originality of his ideas formulated through a long travail oriented towards solving certain obscure problems of the history of Romanian language. In case of thorny issues, like the origin of Romanian people and language, it often happens that the efforts and results generated by a so comprehensive and complex vision as that of the linguist from Iași are regarded at least with certain reluctance. Thus, some of the theories launched by the founder of the Iași School of Linguisticsalthough significant for Romanian linguistics and/or for the views of the scholar-have been questioned or outright ignored by the specialists ${ }^{1}$. Nevertheless, those who have acquired in-depth knowledge of his entire conceptual edifice and have assimilated the vast linguistic material which his linguistic doctrine rests upon may acknowledge him as a master of the science of language history, in general, as the one who created a new linguistic conception and a new research method.

In the exegesis of his works, specialists often invoke the myriad of particular facts discussed by him but, in the course of his endeavour, his main interest is not the individual matter but the overall mechanisms which repeat themselves throughout the history of languages. Therefore, though he is chiefly concerned with the origin of Romanian

\footnotetext{
*Email address: enikopaldr@gmail.com.

${ }^{1}$ When the objections derive from the solid and extensive knowledge of the linguistic and thought system of the savant from Iași and from the confrontation, based on scientific truth, of the interpretations given by him with the immediate reality described by him, they are edifying, since they constitute indexes of progress. For instance, the observation according to which the revolutionary ideas of the Romanian linguist sometimes lead him to incorrect or incomplete conclusions (cf. Ivănescu, 1984) is quite legitimate. In other cases, the argumentation becomes erroneous the moment these innovative ideas are considered independently of the context in which they appear and without restoring their relation to the whole created system. As a matter of fact, if the originality and significance of certain ideas of A. Philippide are overlooked, it may (also) be due to the fact that they are insufficiently or only partially known, for they are scattered throughout his works, lost in details or footnotes. This is the case of the theory of the basis of articulation (and the psychological base), for example, which represents the central idea which the entire conception found in Originea românilor [The origin of Romanians] is built upon and which constitutes the essence of his linguistic doctrine.
} 
language, the way in which he explains the transition of Latin to Romanian, as determined by the change of the basis of articulation, constitutes a viable model for all the other Romance languages as well. Similarly, presenting one by one the phonetic contexts in which the transformations of each sound occur, i.e. describing the sound changes of Romanian language determined by the basis of articulation, the scholar aims at a more general purpose (too), namely at showing that during the formation of each and every language (thus not only of the Romanian one) the decisive role is played precisely by the changes occurred within the phonetic domain which provides the peculiar physiognomy of each language. Moreover, unlike many linguists who, in fact, present merely the conditions of the changes but not the causes which produce these changes, A. Philippide proposes perhaps the most realistic theory of the causes of phonetic changes. Besides his numerous contributions made within the history of Romanian language and in the domain of general linguistics, the scholar from Iași also has the merit of having inspired the following generations and having stimulated a series of subsequent meditations, adjustments, and improvements which have been necessary and which could not have been but beneficial to scientific progress.

Editing the fundamental works of Alexandru Philippide or re-editing them, as the case may be, is not only indispensable for pursuing the development of Romanian linguistics, but it is also extremely useful for readers of all times, whether specialists or not. Along with each new edition the text revives each time differently but at all times in accordance with the current needs, since "a reader cannot be but a person of their epoch, and of the environment in which they evolve" (Chirilă, 2016). Thus, re-editing a text belonging to a different epoch, like Originea românilor [The origin of Romanians], first published in 1923/1927, raises a series of problems concerning aspects of both form and content.

The first challenge the editor of such a text must face consists of the deliberation upon the resources and means adopted in order to prepare the encounter between a reader trained to comprehend a text that is fully consistent with the contemporary linguistic norms and the text generated by a different linguistic context which has consequently made the text become dysfunctional or only partially functional, perhaps even obscure, within the context of the reader. If the adjustment of one of the two entities towards the other is inevitable, the manner in which this can be accomplished and the extent to which one or the other may be "sacrificed", either by dispensing with the prerogative of an easy reading, in case of the former, or by disregarding some of its specific constitutive elements, in case of the latter, represents a decision made by the editor ${ }^{2}$. Whatever the case, the gain that the reader might obtain facing a text adapted to his/her needs constitutes a loss suffered by the text in question and vice versa. The adaptation of the text to the reader has its benefits for the latter one but, in fact, it falsifies the text itself, since this kind of approach attributes to it certain facts that do not belong to it and, thus, the text loses its role of functioning as a mirror of the epoch that has produced it. On the contrary, the intact preservation of the text proposed for re-editing has the advantage of providing an accurate image of a certain stage of the language development to which the present-day reader, however, no longer has access or has only limited access, and the whole process of reprinting loses thus its purpose of popularization.

The latest edition of Originea românilor [The origin of Romanians], made by Roxana Vieru and published in 2014 (vol. I) / 2015 (vol. II) by "Alexandru Ioan Cuza" University Press, provides a judicious and well-balanced solution to the problems mentioned above.

The last printed work of Alexandru Philippide, entitled Originea romanilor [The origin of Romanians], represents not only the masterpiece of the scholar from Iaşi but also a reference book of Romanian linguistics, as it is "one of the most valuable works that Romanian science has ever given" (Gafton, 2009). It is one of those books that ought to be pored over several times and read with a pencil in hand, being time and effort consuming for the reader. This aspect has often been noted with respect to the prolixity of the text, as the plethora of information about the subject matter dealt with, the extremely vast linguistic material discussed within it, as well as the numerous

\footnotetext{
2"In practice, throughout centuries, the one that has been usually «sacrificed», assuming the position of an object under constant adaptation, has been the book” (Chirilă, 2016).
} 
clarifications, explanations, and digressions make the text difficult to study (cf. Iordan, 1969; Macrea, 1978), notwithstanding that it "denotes a power of work that must inspire anyone the deepest respect" (Pușcariu, 1924-1926).

Indeed, the monumental work, both in size and content, gathers and explains almost all the ideas the author meditated on during his lifetime, providing a synthesis of his linguistic doctrine concerning the origin and evolution of Eastern Romanity and the generic mechanisms of language formation, functioning and evolvement, broadly speaking.

Thus, the first volume entitled Ce spun izvoarele istorice [What historical sources relate] discusses problems regarding the territory where Romanianism came into being, the Romanized peoples that gave birth to Romanians, the elements of Romanization, the time when Romanians occupied their current territories, and other issues concerning the partition of Romanian dialects. The second volume, structured in two main parts, namely Cespune limba română [What Romanian language relates] and $C e$ spune limba albaneză [What Albanian language relates] respectively, seeks mainly the issue of the territorial partition of the Romanian dialects, providing a comparative study of them. The solutions proposed by the author for certain controversial problems like the primitive homeland of Romanians, the detachment of the current ramifications of Romanian people; the Common Romance, etc. are not always in line with the theories of his time. Nevertheless, the findings reached by closely studying the processes of Romanian language formation and development give him the opportunity to formulate "one of the most notable language theories that has ever been created in the course of time" (Ivănescu, 1984).

As a matter of fact, Originea romanilor [The origin of Romanians] marks a change in the author's conception of language, at least as compared to the one found in Principii de istoria limbii [Principles of language history] (1894), encompassing all that is new in his thinking regarding the domain of general linguistics. According to this, the causes of the lin- guistic states and changes must be sought within the two bases of language: the basis of articulation which designates the articulators and the innate articulatory tendencies and the psychological base which denotes the nature of the psyche as intellect (thinking, knowledge, culture) and sentiment (emotions and volition). In his opinion, the main factor that determines the structure and evolvement of the phonetic system of a language is, with no doubt, the basis of articulation which he (also) relates to race. Thus, the author argues that every language reflects men along with the physical and psychological aptitudes of the race they belong to.

On the whole, the linguistic doctrine of A. Philippide is a realist or materialist doctrine, having anthropological origins, in which sounds and the changes they suffer are material or physical processes, not psychological ones, as they are governed by the conformation of the articulators. Thus, this theory is most attentive to linguistic reality.

As to its basic conception, the edition of Originea romanilor [The origin of Romanians] published in 2014/2015 may be enlisted in the series of editions initiated by G. Ivănescu and Carmen-Gabriela Pamfil (1984) and then followed by G. Ivănescu, CarmenGabriela Pamfil, and Luminița Botoşineanu (2011). Although each of them raises specific problems, either of editing certain yet unpublished manuscripts or re-editing certain already printed texts, the modern editions of the works of A. Philippide show some sort of continuity provided by their editing norms and methodology. Thus, the individual contributions of each separate edition are subsumed under a relatively unitary conception that governs the purpose of the texts and the arrangement thereof.

Apart from certain particular and/or circumstantial $^{3}$ reasons, such as seeking the completion of the works of A. Philippide with yet unpublished texts or replenishing the stock of volumes that has been exhausted ${ }^{4}$, all three editions, whether or not they acknowledge it expressly, aim at the same purposes, namely at popularizing the ideas of the erudite

\footnotetext{
${ }^{3}$ The edition published in 1984 was occasioned (also) by the $50^{\text {th }}$ anniversary of Philippide's death and the $90^{\text {th }}$ anniversary of the inauguration of his Romanian philology course held at the University of Iași, as the editors relate in the Preface.

4"The volumes published by Philippide have long been bibliographical rarities" (ed. 1984). "A book of such an extraordinary scientific value as this one [The origin of Romanians] should be in the collection of anyone interested in culture, in general, or in the history of Romanian people and language, in particular; nonetheless, this book has been scarcely accessible for readers lately" (ed. 2014). "Originea românilor [The origin of Romanians] is found nowadays only in university libraries and, rarely, in the libraries of certain specialists" (ed. 2014).
} 
scholar from Iași and at conceding his rightful place within Romanian linguistics ${ }^{5}$.

Following the model of the text established in the edition of the selected works on language theory (1984), the latest edition of Originea romanilor [The origin of Romanians] aims to offer the readers a text which would raise as few problems, in terms of its form, as possible but which would not distort at all the linguistic peculiarities that make A. Philippide unique $^{6}$. Thus, "in the course of preparing this edition we have had in mind first and foremost to preserve the fingerprint of the author and, secondly, we have been attentive to make the reading easier for the reader (not necessarily specialized in philology)", as the editor herself confesses (ed. 2014, Notă asupra ediției [Note on this edition]) ${ }^{7}$.

Elaborating such an edition undoubtedly required an enormous and prolonged work. Its first stage consisted of making an anastatic reproduction of the first edition. Once the technical processing of the text was finished (i.e. after scanning the printed text, running the obtained images through a font recognition program, correcting the text followed by its rigorous revision), the second, much more laborious, phase could started. This consisted of transforming the text from the form it had at the beginning of the $20^{\text {th }}$ century to the one it is presented in now. The basic principle of processing and transforming the text is conserving the language of the author, however, "the limits are sometimes difficult to establish" (Gafton, 2009). Thus, there are numerous types of concrete situations which may constitute obstacles, since the intervention on certain forms, either by omitting or modifying them, which alter the text but are necessary, may contrast, in a way or another, with the desideratum of conservation. On the other hand, for certain linguistic phenomena, the only clues regarding the author's will are precisely the manner in which the original text was published. However, preserving all the forms as they occur in the editio princeps bears the chance of perpetuating certain oscillations, for instance, which characterize the original text but which could be redundant for the purpose of the new edition. Moreover, it cannot always be determined exactly and solely based on the text being processed whether these oscillating forms represent the deliberate option of the author or they are simply "slips" that the author himself would have revised. Their correct assessment requires thus to compare the text in question with others, this being the only way to reconstruct the specific and preferred language use of the author.

The general concept that directs the interventions and their uniformity was established based on a thorough research and documentation carried out by the editor. This extremely difficult and demanding travail encompasses not only consulting the editing norms employed in various editions of A. Philippide's works but also studying the terminology of the epoch, including the neological phonetic forms adopted by other researchers too, investigating the forms considered to belong to the linguistic norm of the time, though not always correspondent to the archaic and dialectal language of the author, as well verifying the place names in maps, checking the quotes and bibliography. At the end of this substantial effort, the editor manages to conceive a form that respects both the principles of philology and the needs of the users.

The changes made by the editor are presented in the chapter entitled Fapte de limbă modificate [Modified linguistic material] (p.7-26) and they are judiciously well-argued, at every step, and abundantly illustrated by examples. One of these changes consists of updating the orthography and punctuation. With respect to the use of $\hat{\imath}$ in writing,

\footnotetext{
5 "Except for his disciples [...] only a few linguists of the following generations have carried on with his theories and acknowledge him as a true master of linguistics, as we believe he is" (ed. 1984). "Re-editing Originea românilor [The origin of Romanians] almost a hundred years after its first edition is meant to ensure the acquaintance with one of the most significant works of Romanian culture", having the "faith that he [A. Philippide] shall be rediscovered by each of the next generations" (ed. 2014).

${ }^{6}$ As a matter of fact, initiated by the professor from Iași, Alexandru Gafton, the idea of starting this editorial project has already been taking shape in 2009 when, as a response to the need for a long-awaited new edition, the task of re-printing is assumed in publicwith the stated purpose to "make the work of A. Philippide available for readers [...] so that, in this way, with our humble power, his memory shall be honoured in Iași”-, also briefly presenting the principles that would guide this edition (see Gafton, 2009). This designed project finally came into being in 2014/2015, due to the tireless effort of Roxana Vieru.

${ }^{7}$ In this respect, the editing technique of the courses gathered in Istoria limbii române [The history of Romanian language] (2011) is quite different, though motivated by the nature of the texts included here. Thus, this edition aims at updating the language of A. Philippide which is "full of folk and archaic elements, even as compared to the language of his contemporaries" (ed. 2011, Notă asupra ediției [Note on this edition]).
} 
for instance, the edition adopts the norms used immediately before the 1993 spelling reform, thus following and preserving the spelling favoured by A. Philippide, which is also promoted nowadays by the Iași School of Linguistics. In contrast to this, the spelling of the ethnonym is changed from romin to român, since "the spelling romîn would be not only outdated but also nonsensical and pointless for the present-day audience" (p. 7). Other modifications concern the uniformization and correction, where necessary, of proper names and place names. Regarding the spelling with capital letters or lower-case letters, the spelling of compound words (written as solid compounds, hyphenated compounds or spaced words), and the orthography of other specific forms, the edition takes into account the norms currently in force. As a matter of fact, the spelling adaptation of certain forms, such as the words in which the dental nasal $n$ is noted regardless whether it is followed by a labial (as in dinpotrivă 'on the contrary', inbracă 'to dress', inpreună 'together', etc.), the words formed with the prefix $i n-$ written with a single dental nasal regardless whether it is attached to a root that begins with $n$ (as in inebuni 'to go mad', inopta 'to spend the night', reinoi 'to renew', etc.), the words with $-u$ ending, the words or syllables beginning with $e$ but written without an iota (as in ertarea 'forgiveness', nevoe 'need', trebue 'have to, must', etc.), which represent visual aggressions these days, is all the more justified, since these spellings do not reflect a phonetic reality of that time either.

Except for these kinds of changes, the present edition aims at preserving and valorising the language used by the distinguished professor from Iași. This aspect is briefly presented in the section entitled Fapte de limbă păstrate [Preserved linguistic material] (p. 26-33). Thus, the edition maintains certain phonetic phenomena which characterize the utterances of the author and which are different from those in use today, some of them being in accordance with the pronunciation of the epoch, others being specific to Philippide. The same preserving method is used when dealing with certain grammatical forms which, besides the phonetic particularities, reflect the linguistic reality of Moldavia (or a certain region thereof) at the time the original work was written by its author.
The works of A. Philippide should at all times be made available to linguists or those interested in language, just like the fundamental works of general linguistics have always been accessible to readers, some of them having several editions too. We believe that this directive is most honourably accomplished with the edition made by Roxana Vieru.

In the two volumes edited by the young lecturer, the access of the readers to the extremely complex and dense conceptual content is facilitated by the rigorously and consistently employed critical (technical and scientific) apparatus which provides the text with a remarkable coherence, at its formal level, that is not always found in the original text. The uniformization and updating of the spelling, as the case may be, the substantial changes in its punctuation brought up to date, the corrections of obvious mistakes or those noted by the author himself in the original errata, the correction, completion, and reorganization of the bibliography, the verification and, if necessary, the correction of the quotes, including the fragments recorded in Greek and Latin by the author, etc. aim at the same purpose. By performing these operations, the editor provides the readers with a coherent and comprehensible text that is devoid of the inconsistencies which have made the work difficult to read or which have given rise to confusions so far. Besides these, the indication of the page numbers from the original edition is quite efficacious, since it enables the readers to identify the passages that different researchers have referred to up until the present time. Furthermore, the index of words, grammatical forms, and derivative elements, as well as the index of authors created by the editor represent a very useful tool for readers.

Similarly to the previous editions of A. Philippide's works, the new edition of Originea românilor [The origin of Romanians] is provided with an introductory study (cf. Prefață [Preface], p. 35-51) which synthesizes the main ideas of the book and which makes the edition even more valuable ${ }^{8}$. This study written by Carmen-Gabriela Pamfil, which reproduces certain passages from previously published papers of the author, offers a general overview of the language history issues that preoccupied the scholar from Iași. It also presents the merits of his

\footnotetext{
${ }^{8}$ It is noteworthy that the 1984 edition is remarkable, among other things, precisely for its introductory study written by G. Ivănescu which, in our opinion, is the most comprehensive, just, and valuable account of A. Philippide's linguistic theory.
} 
fundamental work, the relation between Originea românilor [The origin of Romanians] and his lectures gathered in Istoria limbii române [The history of Romanian language] (2011), the main theories of A. Philippide regarding the origin of Romanian people and language, the novelty that this book brings as compared to other studies of the time, including observations on certain outdated ideas and encompassing the necessary rectifications made by his disciple G. Ivănescu. Therefore, this comprehensive study not only presents the conceptual system created by the Romanian linguist but also notes the progress made ever since within Romanian linguistics.

Last but not least, the Postface written by Alexandru Gafton is also quite edifying. It offers essential data regarding the epoch, the scientist and his work, the book entitled Originea romanilor [The origin of Romanians], and the present edition, as the author structures and orders his observations. What is remarkable is that the author places the Romanian linguist within his epoch in a less common way but presenting the scholar as being perfectly integrated into his own time and providing an image that is necessary for understanding the actual state of affairs in those times. Thus, the author does not only establish the linguistic context of the time, as it has been done in most of the cases, but he also broadens the horizons by encompassing and emphasizing what was common to all endeavours - of both natural and human sciences-undertaken in Europe in the $19^{\text {th }}$ century. This widened perspective-adopted only by a few of those who have studied the existential and cultural setting of Philippide's activity - gives the author the opportunity to describe the spirit of an extremely fertile age of science (also) marked by The Origin of Species. It is within this time, which was "one of the brightest epochs of humanity" (p. 629), that the scientist A. Philippide and his work are set, showing that the linguistics practiced by him is incorporated in his world view.

By promoting the same manifold qualities that the founder of the Iași School of Linguistics has featured-namely the thorough enquiry, the careful examination of facts, meticulousness, the precise research method, competence, and efficiency-and bypassing the obstacles raised by the endeavour of such an amplitude, also showing great seriousness, exemplary conscientiousness and scrupulosity, sense of responsibility and moral duty toward the illustrious predecessor, the present edition does not only pay tribute to the scholar and his work, but it also has all the requirements to become a reference edition, if not the sole reference edition, of the new generations of specialists.

\section{References}

Chirilă, A. (2016). Towards a history of the Romanian punctuation, in "Diacronia”, no. 3, Feb. 12, art. A33, CrossRef.

Gafton, Al. (2009). Originea românilor - piatră de temelie a Şcolii lingvistice de la Iași [The origin of Romanians - the cornerstone of the Iași School of Linguistics], in "Philologica Jassyensia”, V, no. 1, p. 51-55.

Iordan, I. (1969). Alexandru I. Philippide, Editura Științifică, București.

Ivănescu, G. (1984). Alexandru Philippide - teoretician al limbajului [Alexandru Philippide - theoretician of language], in Philippide, 1984, p. IX-XLVI.

Macrea, D. (1978). Alexandru Philippide, in Contribuții la istoria lingvisticii și filologiei românești [Contributions to the history of Romanian linguistics and philology], Editura Științifică, București.

Philippide, A. (1894). Principii de istoria limbii [Principles of language history], Tipografia Națională, Iași.

Philippide, A. (1923/1927). Originea rominilor [The origin of Romanians], vol. I, Ce spun izvoarele istorice [What historical sources relate], vol. II, Ce spun limbile romînă și albaneză [What Romanian and Albanian languages relate], Tipografia „Viața românească”, Iași.

Philippide, A. (1984). Opere alese. Teoria limbii [Selected works. Theory of language], edited by G. Ivănescu and Carmen-Gabriela Pamfil, with an introductory study and comments by G. Ivănescu, Editura Academiei, București.

Philippide, A. (2011). Istoria limbii române [The history of Romanian language], critical edition by G. Ivănescu, Carmen-Gabriela Pamfil, and Luminița Botoșineanu, Editura Polirom, Iași.

Pușcariu, S. (1924-1926). Pe marginea cărților, in "Dacoromania”, IV. 